\title{
Deletion of the a subunit of the heterotrimeric Go protein impairs cerebellar cortical development in mice
}

\author{
Hye Lim Cha ${ }^{1 \dagger}$, Jung-Mi Choi ${ }^{1 \dagger}$, Huy-Hyen Oh ${ }^{1}$, Narayan Bashyal ${ }^{1,2}$, Sung-Soo Kim ${ }^{1}$, Lutz Birnbaumer ${ }^{3,4}$ and
} Haeyoung Suh-Kim ${ }^{1,2^{*}}$ (D)

\begin{abstract}
$G_{0}$ is a member of the pertussis toxin-sensitive $G_{i / o}$ family. Despite its abundance in the central nervous system, the precise role of $G_{0}$ remains largely unknown compared to other $G$ proteins. In the present study, we explored the functions of $G_{0}$ in the developing cerebellar cortex by deleting its gene, Gnao. We performed a histological analysis with cerebellar sections of adult mice by cresyl violet- and immunostaining. Global deletion of Gnao induced cerebellar hypoplasia, reduced arborization of Purkinje cell dendrites, and atrophied Purkinje cell dendritic spines and the terminal boutons of climbing fibers from the inferior olivary nucleus. These results indicate that $G_{o}$-mediated signaling pathway regulates maturation of presynaptic parallel fibers from granule cells and climbing fibers during the cerebellar cortical development.
\end{abstract}

Keywords: $G_{0}$ alpha subunit ( $G_{0}$, GTP-binding protein alpha subunit of $G_{0}$ ), Purkinje cell, Cerebellum, Hypoplasia, Synaptic boutons, Climbing fiber, Cerebellar development

\section{Introduction}

When G-protein coupled receptors (GPCRs) bind their cognate ligands, their respective heterotrimeric GTP binding proteins (G-proteins) are activated, inducing the

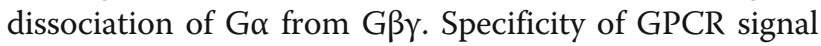
transduction is determined by the functions of the specific $G \alpha$ subunits because all G-proteins share a pool of $\mathrm{G} \beta \gamma$ subunits. $G \alpha$ subunits are classified into four subfamilies: $\mathrm{G \alpha}_{\mathrm{s}}, \mathrm{G \alpha}_{\mathrm{i} / \mathrm{o}}, \mathrm{G \alpha}_{\mathrm{q} / 11}$, and $\mathrm{G \alpha}_{12 / 13}$. So far, 16 different mammalian $G \alpha$ subunits have been identified $[1,2]$. $G_{0}$ belongs to the pertussis toxin-sensitive $G_{i / o}$ family, the $\alpha$ subunits of which share $71 \%$ amino acid sequence homology. $\mathrm{G \alpha}_{\mathrm{i}}$ proteins are ubiquitously expressed and well-studied. They inhibit adenylyl cyclase (AC) directly and consequently reduce intracellular cyclic AMP (cAMP) levels [3]. Gnai (the gene encoding $G \alpha_{i}$ protein)

\footnotetext{
*Correspondence: hysuh@ajou.ac.kr

${ }^{\dagger}$ Hye Lim Cha and Jung-Mi Choi contributed equally to this work.

${ }^{1}$ Departments of Anatomy, Ajou University School of Medicine, Woldcup-ro

164, Yeongtong-gu, Suwon 16499, South Korea

2Departments of Biomedical Sciences, The Graduate School, Ajou University

School of Medicine, World cup-ro 164, Yeongtong-gu, Suwon 16499, South

Korea

Full list of author information is available at the end of the article
}

knockout $\left(\right.$ Gnai $\left.^{-/-}\right)$mice show several abnormalities, especially in their immune systems and blood clotting $[4,5]$. In comparison, $G \alpha_{o}$ expression is restricted to the central nervous system (CNS), particularly in synapses, and to endocrine cells and cardiac myocytes [3, 6, 7]. Accordingly, Gnao (the gene encoding $\mathrm{G \alpha}_{\mathrm{o}}$ protein) knockout $\left(\mathrm{Gnao}^{-/-}\right)$mice show severe neurological deficits including seizures, hyperactivity, and abnormal sexual behavior accompanied by early death $[8,9]$. Mutations of Gnao gene in human patients induce early infantile epileptic encephalopathy (EIEE), which is the basis for the Gnao to be called EIEE17 [10, 11]. These findings suggest $G \alpha_{o}$ plays an important role in the CNS. Still, compared to $G_{i}$, the role of $G_{o}$ in the CNS is largely unknown. This is likely due to the fact that no enzymatic functions have yet been associated with $\mathrm{G \alpha}_{\mathrm{o}}$ and to the fact that the scarcity of $\mathrm{Gnao}^{-1-}$ mice due to their low birth and survival rates make $\mathrm{G \alpha}_{\mathrm{o}}$ difficult to study.

$\mathrm{G \alpha}_{\mathrm{o}}$ is abundantly found in the neurite tips and growth cones of in vitro cultured neurons where it stimulates neurite formation $[7,12,13]$. In $\mathrm{Gnao}^{-/-}$mice, the olfactory nerve layer comprised of projecting axons of olfactory sensory neurons is atrophied, which may be 
associated with defective $G \alpha_{o}$ signals in neurite outgrowth [9]. $\mathrm{G \alpha}_{\mathrm{o}}$ is highly expressed in the cerebellar cortex [14], however, the function of $G_{o}$ in the cerebellum is mostly unknown except for the interaction with the Purkinje cell protein 2, Pcp2 (L7) [15] and $\mathrm{G}_{\mathrm{i} / \mathrm{o}}$-coupled cannabinoid receptor 1 (CB1) [16]. Pcp2(L7) ${ }^{-/-}$mice are almost normal, showing only mild hypoplasia accompanied by normal motor learning and enhanced motor function [17]. WIN55212-2, a CB1 receptor agonist predominantly activates $\mathrm{G \alpha}_{\mathrm{o}}$ among various G-proteins in the rat cerebellum [16].

The cerebellum is a well-defined neural system that can help clarify the correlation between the anatomical architecture of a neural network and its function [18]. The cerebellar cortex consists of three distinct layers: the molecular layer (ML), the Purkinje cell layer (PCL), and the granule cell layer (GCL). Purkinje cells (PCs) arranged in a single layer of the PCL, each sending a single, long axon to deep cerebellar nuclei (DCN) and are the only output neurons of the cerebellar cortex. Their complex dendrites extend through the ML where they receive presynaptic inputs from climbing fibers (CFs) projecting from the inferior olivary nucleus (ION) and parallel fibers (PFs) originating in granule cells (GCs). The PC dendrites are segregated into proximal and distal territories during the postnatal period [19]. Immature proximal PC dendrites are first innervated by multiple CFs during the initial 3 weeks of the postnatal period. During the subsequent 3 weeks, a single dominant CF moves toward the pial surface while the other redundant CFs are pruned [20]. Simultaneously, the immature PCs undergo a transformation from multi- to mono-planarity as they acquire the fan-like shape that is typical for mature PCs [21]. These morphogenetic processes are controlled cell-autonomously by intrinsic PC factors in the early phases of postnatal development and by extrinsic synaptic connections with ION-CFs in the later phases [22].

Various types of $\mathrm{G} \alpha$ proteins are expressed in PCs such as $G \alpha_{\mathrm{q}}, G \alpha_{\mathrm{o}}, G \alpha_{\mathrm{i} 2}$, and $G \alpha_{\mathrm{z}}$. In PC dendrites, $G \alpha_{\mathrm{z}}$ is constantly increased over development, whereas $\mathrm{G} \alpha_{\mathrm{q}}$ and $\mathrm{G \alpha}_{\mathrm{o}}$ show different temporal peaks of gene expression patterns during development stages [23], which suggested that the specificity of $G \alpha_{q}$ and $G \alpha_{o}$ in the developmental changes of PCs. During the cerebellar development, $\mathrm{G} \alpha_{\mathrm{q}}$-mediated signaling cascades [metabotropic glutamate receptor type 1 (mGluR1)-Ga $\alpha_{\mathrm{q}}$ phospholipase C $\beta 4$ (PLC 34 )-protein kinase $\mathrm{C \gamma}$ (PKCY) ] are well-studied. Deletion of each component evokes the similar phenotypes including multiple CF innervation, motor discoordination, and ataxia [24-26].

In this study, we investigate possible roles of $\mathrm{G \alpha}_{\mathrm{o}}$ in cerebellar cortical development using $\mathrm{Gnao}^{-/-}$mice. These results showed that the defective $\mathrm{G \alpha}_{0}$ signals prevent the proper development of presynaptic PFs and CFs as well as maturation of postsynaptic PC dendrites. Our results indicate that $G \alpha_{o}$ is essential for full PC differentiation and the refinement of presynaptic CFs during the postnatal development.

\section{Methods}

\section{Mouse genetics}

$\mathrm{Gnao}^{-/-}$mice were generated by breeding $\mathrm{Gnao}^{+/-}$mice. Hemizygotes were created via the insertion of a neomycin selection cassette at Gnao exon 6 [8]. Tail-genomic DNA was used for genotyping by polymerase chain reaction (PCR) using the following primers that allowed us to verify the disruption of the Gnao gene: int6R1 ( $5^{\prime}$ ACC TGG CCT CCC TTG GGA ATA CAG - 3') and ex6F1 (5' - CAG CGA TCT GAA CGC AAG AAG TGG $-3^{\prime}$ ) for wild type, and int6R1 and pol2R1 (5'- TGT GCT CTA GTA GCT TTA CGG AGC - 3') for mutant. The number of animals used for each quantitative analysis is described in each figure legend. All experimental procedures were reviewed and approved by the Institutional Animal Research Ethics Committee at Ajou University Medical Center (Suwon, South Korea). All mutant mice were compared to the wild type littermate control mice.

\section{Cerebellar neuron culture}

PCs were cultivated according to previous reports [27, 28] with slight modifications. Briefly, the extracted cerebella from $\mathrm{C} 57 \mathrm{BL} / 6 \mathrm{~N}$ at postnatal day $(\mathrm{P}) 0$ were minced with a surgical knife, washed with Hank's balanced salt solution (HBSS; Sigma-Aldrich, \#H2387) containing gentamicin $(50 \mu \mathrm{g} / \mathrm{ml}$, Sigma-Aldrich, \#G1914), and incubated in Accumax solution (Sigma-Aldrich, \#A7089) for $15 \mathrm{~min}$ at $37^{\circ} \mathrm{C}$ in a $5 \% \mathrm{CO}_{2}$ incubator. After washing with $\mathrm{HBSS}$, the tissues were triturated by repetitive pipetting and the debris was removed by passing the suspension through a nylon mesh. After centrifugation of the cell suspension, the cell pellet was resuspended in plating medium containing $10 \%$ (vol/vol) fetal bovine serum (FBS; Hyclone, \#SH30084.03) and $50 \mu \mathrm{g} / \mathrm{ml}$ gentamicin in Dulbecco's modified Eagle medium/F12 (DMEM/F12; Gibco, \#11330032 ) and then plated onto coverslips coated with poly-Dlysine (PDL; $0.1 \mathrm{mg} / \mathrm{ml}$, Sigma-Aldrich, \#P6407) and laminin $(10 \mu \mathrm{g} / \mathrm{ml}$, Gibco, \#23017-015). After $2 \mathrm{~h}$, the cells were washed with HBSS and the medium was replaced with Neurobasal-A medium (Gibco, \#10888-022) containing B27 (Gibco, \#17504-044), Glutamax (Gibco, \#35050061), and Penicillin-Streptomycin (10,000 U/ml, Gibco, $\# 151-40,122)$. To culture GCs, C57BL/6 N mice were sacrificed at $\mathrm{P} 7$ when external granule cells extensively proliferate $[29,30]$. Cerebellar cells were isolated and purified as described [31]. 


\section{In situ hybridization}

The template DNA for in vitro transcription-Gnao exons 4 and 5 (nt 767-914, NM_010308.3)-was chosen for the preparation of RNA probes to avoid any regions of homology with Gnai2. The cDNA encompassing exons 4 and 5 (148 bp) was amplified with a forward primer (5'CTT TGG GCG TGG AGT ATG GTG-3') and a reverse primer (5'-CTC CTG GAT CCC CGA GTC GCC C-3'). The PCR product was then sub-cloned into the pGEM-T easy plasmid (Promega, \#A1360). This plasmid was linearized with Nco I (Roche, \#10835315001) or Sal I (Roche, \#10348783001) for preparing the antisense- or sense-stranded RNAs, respectively. The antisense RNA was in vitro transcribed using SP6 RNA polymerase and a UTP-11-fluorescein isothiocyanate (FITC) labeling kit (Roche, \#11685619910). Cryostat brain sections (40 $\mu \mathrm{m}-$ thick) were dried at room temperature $\left(23 \pm 2{ }^{\circ} \mathrm{C}\right)$ for 30 min and fixed in $10 \%$ neutral buffered formalin (NBF; BBC biochemical, \#0151) for $10 \mathrm{~min}$. After washing with diethylpyrocarbonate (Sigma-Aldrich, \#D5758)-treated phosphate buffered saline (DEPC-PBS), the sections were acetylated with $0.1 \mathrm{M}$ triethylamine (TEA, pH 8.0; Sigma-Aldrich, \#T0886) and $2.5 \%$ acetic anhydride (Sigma-Aldrich, \#A6404) in DEPC-PBS for $10 \mathrm{~min}$ at room temperature. The sections were then dehydrated and defatted with a 5-min chloroform (Sigma-Aldrich, \#36919) treatment. Then, the sections were rinsed with ethanol, air dried, and stored at $-70{ }^{\circ} \mathrm{C}$ until used. The sections were pre-warmed at $55^{\circ} \mathrm{C}$ for $15 \mathrm{~min}$ and pretreated at $37^{\circ} \mathrm{C}$ for $2 \mathrm{~h}$ in hybridization solutions (Sigma-Aldrich, \#H7782) supplemented with $0.2 \mathrm{~g} / \mathrm{ml}$ dextran sulfate (Sigma-Aldrich, \#D8906), 50\% (vol/vol) formamide (Sigma-Aldrich, \#F9037), $1 \mathrm{mg} / \mathrm{ml} \mathrm{Herring's}$ sperm DNA (Sigma-Aldrich, \#D7290), and $1 \mathrm{mg} / \mathrm{ml}$ Ribonucleic acid from torula yeast (Sigma-Aldrich, \#R6625) in 1.5× saline-sodium citrate (SSC; Invitrogen, \#AM9763). Hybridization was performed in the presence of $0.1 \mu \mathrm{g} / \mu \mathrm{l}$ FITC-labeled RNA probe for $40 \mathrm{~h}$ at $37^{\circ} \mathrm{C}$. Then, unbound the probe was removed by sequential washing with $2 \times$ SSC for $5 \mathrm{~min}$ at room temp, $1 \times$ SSC for $1 \mathrm{~min}$ at room temp, $0.5 \times$ SSC containing $0.1 \%$ sodium dodecyl sulfate (SDS; Sigma-Aldrich, \#L4390) for $20 \mathrm{~min}$ at $55^{\circ} \mathrm{C}, 0.1 \times$ SSC containing $0.1 \%$ SDS for $20 \mathrm{~min}$ at $55^{\circ} \mathrm{C}, 0.1 \times$ SSC containing $0.1 \%$ SDS for $20 \mathrm{~min}$ at room temp twice, and finally Trisbuffered saline (TBS, pH 7.5) without SDS for $5 \mathrm{~min}$ at room temperature 3 times. The sections were counterstained with bisbenzamide (Hoechst 33258; Invitrogen, \#H3569) and mounted using Fluoromount$G^{\circ}$ mounting solution (Southern Biotech, \#0100-01). Images were acquired using an LSM710 confocal microscope (Carl Zeiss). Sense probes were generated with T7 RNA polymerase and used to verify Gnaospecific signals.

\section{Immunofluorescence analysis}

Mice were deeply anesthetized by i.p. injection of 2,2,2tribromoethanol $(0.02 \mathrm{ml} / \mathrm{g}$, Sigma-Aldrich, \#T48402) and perfused transcardially with $10 \% \mathrm{NBF}$. Extracted brains were incubated overnight in $10 \% \mathrm{NBF}$ at $4{ }^{\circ} \mathrm{C}$ for post-fixation. For frozen sections, the brain was placed in $30 \%$ sucrose (Sigma-Aldrich, \#S7903) in $0.1 \mathrm{M}$ phosphate buffer ( $\mathrm{pH} 7.4$ ) at room temp for $48 \mathrm{~h}$ and embedded in O.C.T compound (Tissue-Tek, Sakura Finetek, \#4583) to cut into $30 \mu \mathrm{m}$-thick slices. For paraffin sections, the brain was embedded in paraffin (Merck, \#1.15161.2504) following standard procedures and cut into $7 \mu \mathrm{m}$-thick slices. To perform the staining, epitopes were unmasked by microwave (Daewoo Electronics, South Korea)-heating in $10 \mathrm{mM}$ sodium citrate ( $\mathrm{pH}$ 6.0; Sigma-Aldrich, \#S4641) buffer including 0.05\% (vol/vol) Tween 20 (Anatrace, \#T1003) at $95^{\circ} \mathrm{C}$ for $15 \mathrm{~min}$. The samples were incubated with blocking solution $[10 \%$ (vol/vol) normal goat serum (Gibco, \# 16210-072), 1\% bovine serum albumin (BSA; Sigma-Aldrich, \#A2153) and $0.1 \% \quad(\mathrm{vol} / \mathrm{vol})$ Triton X-100 (Sigma-Aldrich, \#T8787) in PBS (T-PBS)] for $1 \mathrm{~h}$ at room temp. The sections were incubated with primary antibodies overnight at $4{ }^{\circ} \mathrm{C}$. The antibodies used were specific for $\mathrm{G \alpha}_{\mathrm{o}}$ (1: 200, rabbit, Santa Cruz, \#SC-387), Calbindin-D28K (Calb, 1:100, mouse, Sigma-Aldrich, \#C9848 and 1:200, rabbit, Swant, \#CB38a), Pcp2 (1:200, mouse, Santa Cruz, \#SC-137064), vesicular glutamate transporter 1 (vGluT1, 1:100, rabbit, Invitrogen, \#48-2400), vesicular glutamate transporter 2 (vGluT2, 1:100, mouse, Millipore, \#MAB5504), and Tubulin $\beta$-III (Tubb3; 1:500, mouse, Biolegend, \#801201). After washing with T-PBS, sections were incubated with secondary antibodies conjugated with Alexa 488 or 568 (Invitrogen) for $1 \mathrm{~h}$ at room temperature. The sections were counterstained with bisbenzamide and mounted as described above.

For immunocytochemistry, the coverslips with live cells attached were fixed with $10 \%$ NBF for $10 \mathrm{~min}$ at room temperature. After washing, the coverslips were incubated with blocking solution to block non-specific signals for $1 \mathrm{~h}$ at room temp and then incubated with primary antibodies overnight at $4{ }^{\circ} \mathrm{C}$. The samples were incubated in the presence of secondary antibodies and mounted as described above. All fluorescence images were acquired using an LSM710 confocal microscope (Carl Zeiss) or a slide scanner Axio-Scan.Z1 slide scanner (Carl Zeiss). Isotype-specific IgG or normal serum were used instead of the primary antibody to validate the specificity of the immunoassays.

\section{Western blot analysis}

Approximately $100 \mathrm{mg}$ of brain tissue was homogenized in $1 \mathrm{ml}$ RIPA buffer (50 mM Tris-Cl, pH 8.0, 1\% (vol/vol) IGEPAL $^{\circ}$ CA-630 (Sigma-Aldrich, \#I8896), 0.1\% SDS, 
0.5\% sodium deoxycholate (Sigma-Aldrich, \#D6750), $150 \mathrm{mM}$ Sodium chloride (Affymetrix/USB, \#21618). The homogenate was centrifuged at $14,000 \mathrm{x} g$ for 10 min at $4{ }^{\circ} \mathrm{C}$ and the supernatant was used for western blot analysis with anti- $\mathrm{G \alpha}_{\mathrm{o}}$ (1:1000, Santa Cruz), anti$\mathrm{G \alpha}_{\mathrm{i} 1 / 2 / 3}$ (1:1000, Santa Cruz, \#SC-26761), anti- $\mathrm{G \alpha}_{\mathrm{q}}$ (1:500, Santa Cruz, \#SC-136181) and anti-Pcp2 (1:100, Santa Cruz, \#SC-137064) as previously described [32]. The specific immunoreactivity was visualized using a secondary antibody conjugated with horseradish peroxidase (1:5000, Zymed) and an ECL kit (Pierce, \#32106).

\section{Cerebellar surface area measurement}

The cerebella of mice older than P21 were considered mature. $1 \mathrm{~mm}$-thick midsagittal mouse brain sections were obtained using a mouse brain matrix (ASI-Instruments, RBM-2000C) and used to make paraffin blocks. Paraffin-embedded cerebellar sections $(7 \mu \mathrm{m}$-thick) were de-paraffinized via standard procedures and stained with cresyl violet (Sigma-Aldrich, \#C5042) or nuclear fast red solution (Sigma-Aldrich, \#N3020) for 1-5 min at room temperature. The sections were mounted using Cytoseal ${ }^{\mathrm{m}}{ }^{\mathrm{T}}$ XYL (Thermo Scientific, \#8312-4) and scanned with Aperio Scanscope XT scanner (Aperio Technologies). Cresyl violet-stained images of the whole cerebellar sections and the GCL were obtained, converted to black-andwhite, and used to measure the occupancy of the GCL and ML via the ImageJ 1.50 program (NIH) [33]. The area covered by the ML was measured by subtracting the area covered by the GCL and white matter from the area of the whole cerebellum.

\section{Measurement of PC dendrites and CF boutons}

To measure the thickness of PC dendrites, paraffin sections $\left(7 \mu \mathrm{m}\right.$-thick) from $\mathrm{Gnao}^{-/-}$mice were stained with an anti-Calbindin antibody. Fluorescent images were taken with an LSM710 confocal microscope using a 63X-oil immersion objective. $50 \mu \mathrm{m}$-long dendrites were selected from the confocal images. The thickness of each PC dendritic trunk was measured at a distance of one cell-body diameter from the cell body as described [34].

To measure spine length and density, all types of spines (i.e., protrusions, stubby, filopodia, and mushroomtype spines) were counted within a $10 \mu \mathrm{m}$ stretch of distal dendrite in $\mathrm{Gnao}^{-/-}$mice and their wild-type littermates, $\mathrm{Gnao}^{+/+}$. According to the typical criteria for classifying dendritic spines, only spines separated from the dendritic shaft by at least $0.5 \mu \mathrm{m}$ were counted [35]. vGluT2positive CF boutons were counted on $50 \mu \mathrm{m}$ stretches of the main dendritic trunks from $\mathrm{Gnao}^{-/-}$mice and $\mathrm{Gnao}^{+/+}$mice. The size of the vGluT2-positive fluorescent boutons was measured in a $200 \mu \mathrm{m}$-wide area of the ML from lobule II/III of each genotype. All quantifications for these results were performed semi-automatically using the Image 1.50 software package (NIH).

\section{Statistical analysis}

Statistical analyses were performed to determine any significant differences between two groups by two-tailed unpaired t-tests using the GraphPad Prism 8 (GraphPad Software Inc.) or SigmaPlot 12.0 software (Systat Software, Inc.). All quantitative values are presented as means \pm Standard error of mean (SEM). For all tests, $p<0.05$ is considered significant and $p$ values are presented in the results and/or figure legends.

\section{Results}

$\mathrm{Ga}_{\mathrm{o}}$ is required for cerebellar cortex development

The anatomical development of the cerebellar lobules is completed around P21 [36]. Although the survival rates of $\mathrm{Gnao}^{-/-}$mice is extremely low, we were able to analyze the cerebella of the few $\mathrm{Gnao}^{-/-}$mice that survived to P180. To avoid lobular differences, we used sagittal sections of the vermal region in all experiments. Cresyl violet staining showed that the lack of $\mathrm{G \alpha}_{\mathrm{o}}$ does not alter the overall lobulation of the cerebellar cortex; the only significant difference we observed in Gnao mice was a $62 \%$ reduction in the depth of the intercrural fissure between lobules VI and VII [37] $(0.25 \pm 0.02 \mathrm{~mm}$ in $\mathrm{Gnao}^{+/+}$mice; $0.10 \pm 0.04 \mathrm{~mm}$ in $\mathrm{Gnao}^{-/-}$mice; $n=3$ mice for each genotype $\geq \mathrm{P} 25$; " $p<0.05$; arrows in Fig. 1a$\mathrm{b}$, and g). The overall size of the cerebellum was also reduced, with the cerebellar surface area in the midsagittal sections of the vermis being $25 \%$ smaller in $\mathrm{Gnao}^{-/-}$ mice compared to $\mathrm{Gnao}^{+/+}$mice $\left(5.9 \pm 0.39 \mathrm{~mm}^{2}\right.$ in $\mathrm{Gnao}^{+/+}$mice; $4.4 \pm 0.23 \mathrm{~mm}^{2}$ in $\mathrm{Gnao}^{-/-}$mice; $n=4$ mice for each genotype $\geq \mathrm{P} 25$; $" p<0.05$; Fig. $1 \mathrm{~h}$ and Additional file 1). This hypoplasia was evident in the ML (Fig. 1c-d), the thickness of which in each folium was reduced by $11 \%$ in Gnao $^{-/-}$mice $(138.6 \pm 2.27 \mu \mathrm{m}$ in $\mathrm{Gnao}^{+/+}$mice; $123.7 \pm 2.16 \mu \mathrm{m}$ in $\mathrm{Gnao}^{-/-}$mice; $n=4$ mice for each genotype $\geq P 25 ; * * * 0.001$; Fig. 1i). Since the thickness and shape of the GCL varies among the folia, we compared the total area occupied by the GCL in $\mathrm{Gnao}^{-/-}$mice to that of their wild-type littermates (Additional file 1). The GCL was reduced to an extent similar to that of the ML $\left(2.4 \pm 0.14 \mathrm{~mm}^{2}\right.$ in $\mathrm{Gnao}^{+/+}$mice; $1.9 \pm 0.01 \mathrm{~mm}^{2}$ in $\mathrm{Gnao}^{-/-}$mice; $n=3$ mice for each genotype $\geq$ P25; $p<0.05$; Fig. $1 \mathrm{j}$ ), and a total number of GCs were reduced by $27 \%$ in $\mathrm{Gnao}^{-/-}$mice compared to their wild-type littermates $\left(155.0^{*} 10^{3} \pm 2.67^{*} 10^{3}\right.$ cells in $\mathrm{Gnao}^{+/+}$mice; $113.7^{*} 10^{3} \pm 5.77^{*} 10^{3}$ cells in $\mathrm{Gnao}^{-/-}$ mice; $n=3$ mice for each genotype $\geq \mathrm{P} 25$; $* p<0.005$; Fig. 1k). Thus, we did not find a significant difference in the occupancy ratios of the ML to the GCL in $\mathrm{Gnao}^{-1-}$ mice compared to their wild-type littermates $(n=4$ for each genotype $\geq$ P25; Fig. 11). 


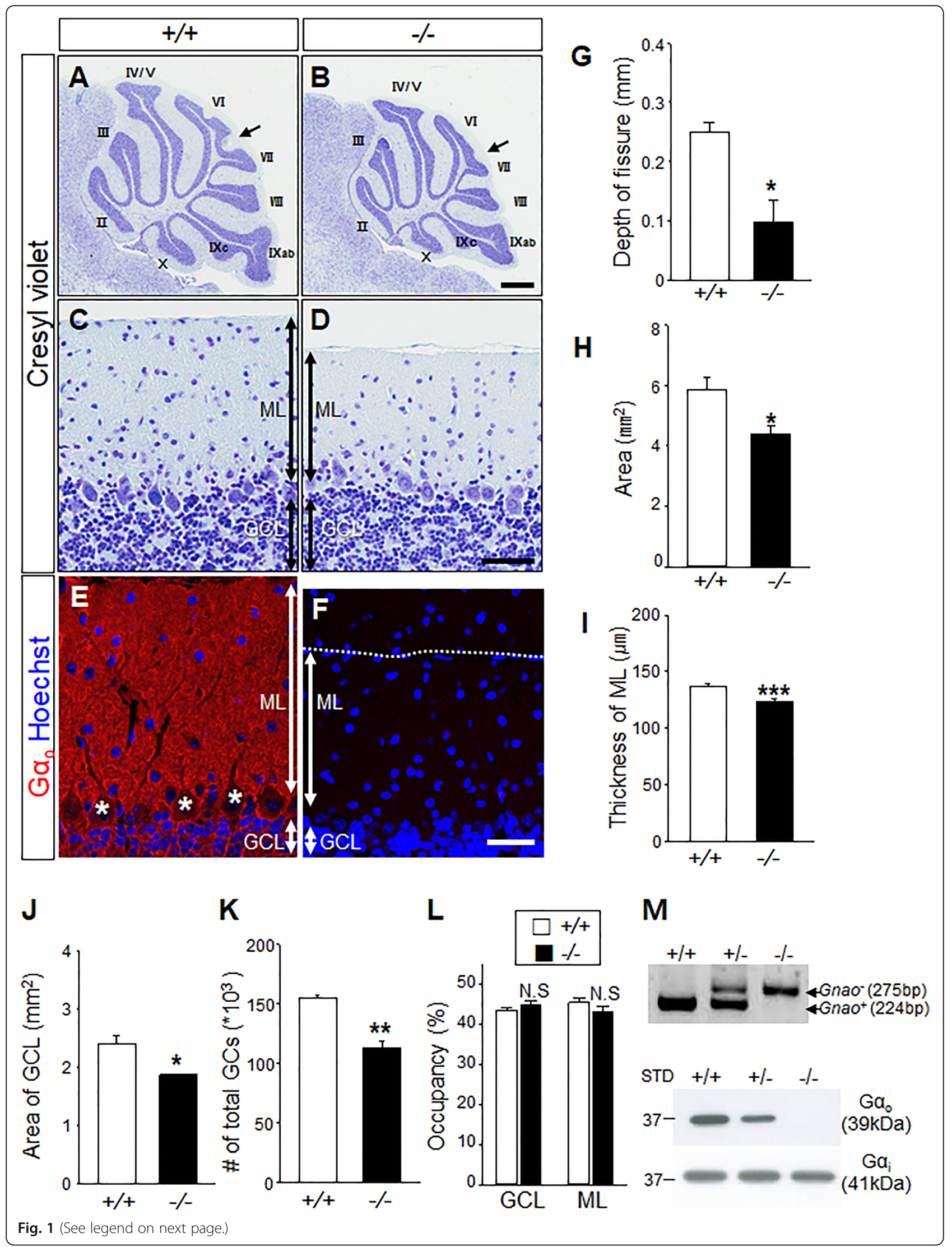


(See figure on previous page.)

Fig. $1 \mathrm{Ga}_{\circ}$ is required for cerebellar cortex development. a-b Overall cerebellum size of Gnao ${ }^{-1-}$ mice is smaller than that of their wild-type $\mathrm{GnaO}^{+/+}$littermates. Both $\mathrm{Gnao}^{+/+}$and $\mathrm{Gnao}^{-/-}$mice show the ten typical cerebellar lobules, but the depth of the folia in lobules VI-VII is reduced in $\mathrm{Gnao}^{-1-}$ mice (arrows). c-d Cresyl violet staining shows the normal arrangement of the three cortical layers. The ML is thinner in $\mathrm{Gnao}^{-/-}$mice than $\mathrm{Gnao}^{+/+}$mice. e-f $\mathrm{Ga}$ is abundant in the $\mathrm{ML}$ and $\mathrm{GCL}$ of $\mathrm{Gnao}^{+/+}$, but undetectable in the $\mathrm{ML}$ and $\mathrm{GCL}$ of $\mathrm{Gnao}^{-/-}$mice. The asterisks in e highlight the absence of $\mathrm{Ga}_{\circ}$ in PC soma. Note the difference of ML thickness. Scale bars, $500 \mu \mathrm{m}$ in $a-b, 50 \mu m$ in $c-f$. $\mathbf{g}$ The intercrural fissure between lobules VI and VII is reduced in $\mathrm{Gnao}^{-/-}$mice. $\mathbf{h}$ Cerebellar areas in mid-sagittal sections are smaller in Gnao ${ }^{-/-}$mice. $\mathbf{i} \mathrm{ML}$ thickness is reduced in $\mathrm{Gnao}^{-/-}$mice $\left(n=119\right.$ sections from $4 \mathrm{Gnao}^{+/+}$mice and 122 sections from $4 \mathrm{Gnao}^{-/-}$mice). $\mathbf{j} \mathrm{GCL}$ occupancy is $20 \%$ lower in $\mathrm{Gnao}^{-/-}$mice than $\mathrm{Gnao}^{+/+}$mice. $\mathbf{k}$ The number of total GCs in the GCL area is reduced by $27 \%$ in $\mathrm{Gnao}^{-/-}$mice. I Occupancy ratios for the GCL (43.4 $\pm 0.73 \mathrm{in} \mathrm{Gnao}+/+$ mice and $44.8 \pm 0.96$ in $\mathrm{Gnao}^{-1-}$ mice; $\left.p=0.300\right)$ and for the ML (45.3 $\pm 0.97 \mathrm{in} \mathrm{Gnao}^{+/+}$mice and $43.1 \pm 1.33$ in $\mathrm{Gnao}^{-/-}$mice; $\left.p=0.248\right)$ are similar when the smaller size of the cerebellum in $\mathrm{Gnao}^{-/-}$mice is taken into account. $\mathbf{m}$ upper. Genotyping shows the mutant $\left(\mathrm{GnaO}^{-}\right)$and the wild type $\left(\mathrm{Gnao}^{+}\right)$ alleles as 275 and $224 \mathrm{bp}$, respectively. Lower. Western blot analysis shows the absence of $\mathrm{Ga}_{\mathrm{o}}$, but not Ga. Data are means $\pm \mathrm{SEM}$; ${ }^{*} p<0.05$, ${ }^{* *} p<0.005$, ${ }_{* * *} p<0.001$ vs. Gnao ${ }^{+/+}$. N.S.; No significant difference, STD; standard marker

Immunostaining with an anti- $G \alpha_{o}$ antibody revealed a broad distribution of $\mathrm{G \alpha}_{\mathrm{o}}$ protein in the ML and GCL (Fig. 1e), but not in the PC somata within the PCL (asterisks in Fig. 1e). We verified the specificity of the anti- $\mathrm{G \alpha}_{\mathrm{o}}$ antibody by confirming an absence of immunoreactivity in $\mathrm{Gnao}^{-1-}$ mice (Fig. 1f) as well by western analysis (Fig. 1m).

\section{$\mathrm{Ga}_{\mathrm{o}}$ is targeted to the synaptic membranes of cerebellar neurons}

The apparent absence of $\mathrm{G \alpha}_{\mathrm{o}}$-immunoreactivity we observed in PC somata within the PCL was not in accordance with previous reports of $\mathrm{G \alpha}_{\mathrm{o}}$ expression in PCs (Table 1). To determine the precise location of $\mathrm{G \alpha}_{\mathrm{o}}$ protein, we performed an immunostaining experiment to detect $\mathrm{G \alpha}_{\mathrm{o}}$ and Pcp2 in the adult cerebellum. Pcp2 is a well-known PC-specific marker that interacts with $\mathrm{G \alpha}_{\mathrm{o}}$ [15]. We observed $\mathrm{G \alpha}_{\mathrm{o}}$ protein in the membrane compartment of PC dendrites but not in the cytosolic compartment of PC soma (Fig. 1e, asterisk), whereas we observed Pcp2 staining both in PC dendrites and soma (Fig. 2a). Importantly, $\mathrm{G \alpha}_{\mathrm{o}}$ was co-localized with Pcp2 in the dendritic spines (Fig. 2a). Such co-localization was evident in the sprouting dendritic tips and in pseudopodial protrusions emerging from the apical pole of early phase PCs in P7 (Fig. 2b). An in situ hybridization experiment revealed the presence of Gnao mRNA in the

Table 1 Comparison of the localization of $\mathrm{Ga}_{\mathrm{o}}$ protein and $\mathrm{Gnao}$ mRNA in the cerebellar cortex. The localization of $\mathrm{Ga}_{\circ}$ protein and Gnao mRNA is compartmentalized in ML, PCL and GCL. Ga。 protein and Gnao mRNA were assessed by immunohistochemistry and in situ hybridization, respectively

\begin{tabular}{llllll}
\hline & Species & ML & PCL & GCL & Ref. \\
\hline Gao protein & Mouse & + & - & + & Figure 1e \\
& & ND & + & ND & {$[23]$} \\
Gnao mRNA & Mat & + & - & ND & {$[14]$} \\
& Mouse & - & + & + & Figure 2b Allen brain atlas \\
& Rat & - & + & + & {$[38,39]$} \\
\hline
\end{tabular}

ahttp://mouse.brain-map.org/experiment/show/507. ND Not Determined perikaryon of PCs, GCs, and interneurons of the ML (arrowheads in Fig. $2 \mathrm{c} 1, \mathrm{c} 2$, and $\mathrm{c} 3$, respectively). $\mathrm{G \alpha} \alpha_{\mathrm{o}}$ protein expression was more evident upon in vitro dissociation in cultured PCs (Fig. 2d). Unlike in the in vivo immunostaining experiment, we observed $G \alpha_{o}$ protein both in PC soma (asterisk) and dendrites (arrows in Fig. 2d). This immunoreactivity showed an overlap with that of anti-Calb, another PC-specific marker (Fig. 2d) . These results indicate $\mathrm{G \alpha}_{\mathrm{o}}$ protein is highly mobile in the membrane compartment after being synthesized in the PC soma. This leads to the apparent absence of $G \alpha_{o}$ protein in the PCL in vivo (Table 1). Further studies with immune-electron microscopy with the $\mathrm{Gnao}^{+/+}$and $\mathrm{Gnao}^{-/-}$mice may clarify this issue. In dissociated cultures of P7 cerebellum in which external granule layer (EGL) cells highly proliferate, we found most cells are Tubb3- and $\mathrm{G \alpha}_{\mathrm{o}}$-positive (Fig. 2e). Considering that GCs greatly outnumber interneurons by 414:1 [40, $41]$, it is very likely most Tubb3- and $G^{\circ}{ }_{o}$-positive cells in Fig. 2e are GCs although Gnao mRNA is expressed both in GCs and interneurons in the ML (Fig. 2c). Thus, the reduced size of the ML indicates a reduced total number of GCs in the absence of G⿰ $\alpha_{\mathrm{o}}$ (Fig. 1k).

\section{$\mathrm{Ga}_{\mathrm{o}}$ is required for the maturation of $\mathrm{PC}$ dendrites}

After immunostaining PFs in $\mathrm{Gnao}^{-/-}$mice with an antivGluT1 antibody, we found a generalized reduction in the thickness of the ML, but no more specific abnormalities (Additional file 2). Immunostaining of $\mathrm{Gnao}^{-1-}$ mice with an anti-Calb antibody revealed no difference in the arrangement and number of PC somata in the PCL in $\mathrm{Gnao}^{-/-}$mice ( $n=4$ for each genotype; Fig. 3a-b, and $\mathrm{g}$ ). We estimated PC monoplanarity by counting the number of PCs with primary dendrites stretching longer than $30 \mu \mathrm{m}$. About $70.3 \pm 6.20 \%$ of the wild-type PCs retained primary dendrites longer than $30 \mu \mathrm{m}$ (Fig. 3c, h), which is consistent with a previous report that roughly $70-80 \%$ PCs are monoplanar after P25 [21]. This suggests our semi-quantitative approach is relevant and indirectly indicates planarity as was previously noted [34]. In comparison, $\mathrm{Gnao}^{-/-}$mice show only $47.1 \pm 4.85 \%$ 


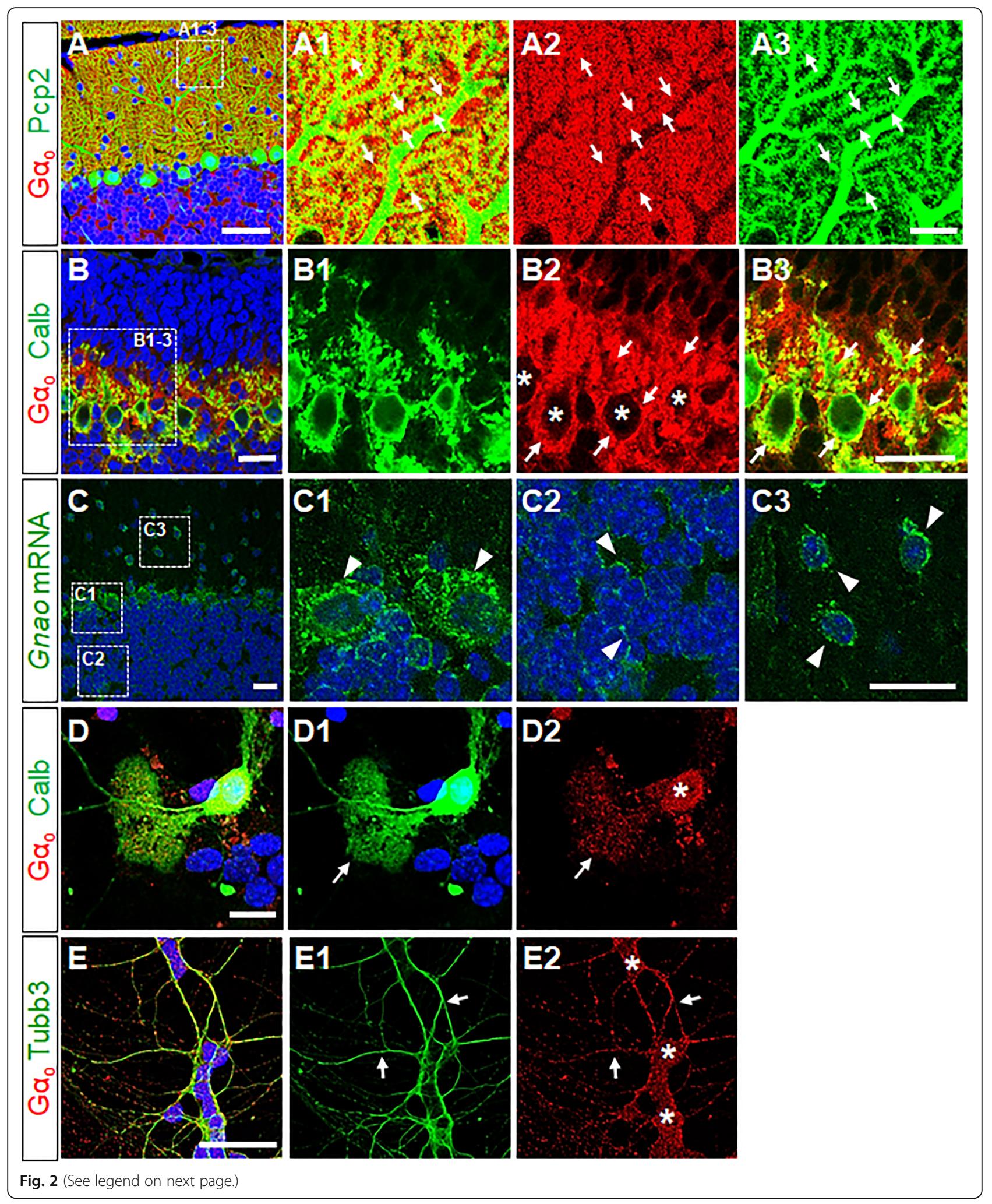


(See figure on previous page.)

Fig. $2 \mathrm{Ga}_{\circ}$ is highly targeted to the synaptic terminal regions of cerebellar neurons in wild-type mice. a Ga-immunoreactivity appears at high levels throughout PC dendrites, especially in Pcp2-positive spines (Arrows in a1-a3, magnified views of a box shown in a). Scale bars, 50 um in a, $10 \mu \mathrm{m}$ in a1-a3. b PCs start to differentiate with many protrusions and neurites in a monolayer. Gao is co-localized with Calb, another PC-specific marker at every PC boundary (yellow, arrows in b2 and b3) except in PC soma devoid of Ga (asterisks in b2). Scale bars, 20 m in b-b3. c Strong Gnao mRNA signals appear in the perinuclear regions of PC soma (c1), GCs (c2), and ML interneurons (c3). Scale bars, $20 \mu \mathrm{m}$ in c, $10 \mu \mathrm{m}$ in c1-c3. d In vitro culture of PCs shows $\mathrm{Ga}_{\mathrm{o}}$ and calbindin-D28K (Calb) expression at 21 days in vitro (DIV). The cultured PCs show significant Ga, signal in the soma (asterisk, d2) and in the dendrites (arrows in d1-d2). e In GCs at DIV7, Ga。 protein appears in the soma (asterisks, e2) and in the neurites (arrows in e1-e2) of Tubb3-positive GCs. Scale bars, $20 \mu \mathrm{m}$ in $\mathbf{d}$-e. Bisbenzimide (Hoechst 33342) staining (blue) was used to visualize cell nuclei in a-e

monoplanar PCs, suggesting that roughly 33\% PCs in $\mathrm{Gnao}^{-1-}$ mice do not acquire monoplanarity during the early postnatal period ( $n=3$ mice for each genotype $\geq \mathrm{P} 25$; * $p<0.05$; Fig. 3d, h). Importantly, we observed a reduction in the thickness of PC dendritic trunks by $25 \%(3.2 \pm$ $0.06 \mu \mathrm{m}$ in $\mathrm{Gnao}^{+/+}$mice and $2.4 \pm 0.06 \mu \mathrm{m}$ in $\mathrm{Gnao}^{-/-}$ mice; $n=3$ mice for each genotype $\geq \mathrm{P} 25$; $* * 0<0.001$; Fig. 3e-f, and i) and in the number of spines by $16 \%$ $\left(1.01 \pm 0.01 / \mu \mathrm{m}\right.$ in $\mathrm{Gnao}^{+/+}$mice; $0.85 \pm 0.01 / \mu \mathrm{m}$ in $\mathrm{Gnao}^{-/-}$mice; $n=3$ mice for each genotype $\geq \mathrm{P} 180$; $* * * 0.001$; Fig. 3j) accompanied by an increase in average spine length by $9 \%\left(0.7 \pm 0.01 \mu \mathrm{m}\right.$ in $\mathrm{Gnao}^{+/+}$ mice; $0.8 \pm 0.02 \mu \mathrm{m}$ in Gnao $^{-1-}$ mice; $n=3$ mice for each genotype $\geq \mathrm{P} 180 ;{ }^{* * *} p<0.001$; Fig. $\left.3 \mathrm{k}\right)$. These data suggest $G \alpha_{o}$ deficiency disrupts the development of the monoplanarity of typical fan-shaped PCs, their dendritic arborization, and their spine formation without affecting their migration or alignment. Interestingly, when we stained $\mathrm{Gnao}^{-/-}$mice and visualized the vGluT2-positive terminal boutons of CFs with vertical extensions along the main dendrite trunks of PCs (Fig. 4a-b), we found a $32 \%$ reduction in the number of CF boutons on PCs $(23.3 \pm 2.02$ in $\mathrm{Gnao}^{+/+}$mice; $16.0 \pm 1.38$ in $\mathrm{Gnao}^{-/-}$mice; $n=4$ mice for each genotype $\geq \mathrm{P} 25$; ${ }^{*} p<0.05$; Fig. $4 \mathrm{c}$ ) and an $11 \%$ reduction in the average size of CF boutons (2.1 \pm $0.05 \mu \mathrm{m}^{2}$ in Gnao $^{+/+}$mice; $1.9 \pm 0.06 \mu \mathrm{m}^{2}$ in $\mathrm{Gnao}^{-/-}$ mice; $n=4$ mice for each genotype $\geq \mathrm{P} 25$; $* p<0.005$; Fig. 4d). This atrophy of CF boutons and PC spines may indicate an essential role for $\mathrm{G \alpha}_{\mathrm{o}}$ in full functional maturation of synapses between presynaptic ION neurons and postsynaptic PCs.

\section{Discussion}

The cerebellum is a useful model utilized for studying many aspects of neural development because of its typical cytoarchitecture and developmental program [42]. In this study, we show that $G_{0}$ plays a crucial role in the postnatal development of the cerebellar cortex. Specifically, Gnao-/- mice exhibit hypoplasia of the cerebellum (Fig. 1 and Additional file 1) with overall defects in cerebellar cortex development. In $\mathrm{Gnao}^{-1-}$ mice, the thickness of the ML and GCL are significantly reduced (Fig. 1) without more specific abnormalities in vGluT1-expression
(Additional file 2), the monoplanarity, dendritic arborization and spinogenesis of PCs are reduced (Fig. 3), and the maturation of CF boutons are atrophied (Fig. 4).

The intensive remodeling and maturation of PC dendrites that occurs during the postnatal period is controlled by intrinsic factors early in development and by a careful orchestration of intrinsic and extrinsic factors later in development [22]. The abnormalities we observed in the PC dendrites and spines of $\mathrm{Gnao}^{-/-}$mice may therefore be either a consequence of the lack of $G_{o^{-}}$ mediated signaling in the PCs themselves (intrinsic factors) or a consequence of their defective formation of synapses with CF boutons (extrinsic interactions).

Intrinsic factors that regulate $\mathrm{Ca}^{2+}$ homeostasis, such as mGluR1 and its downstream signaling pathways, are critical in PCs for the selection of the winning CF and the pruning of redundant CFs that originate in the ION [43]. Mice lacking even a single component of the mGluR1-G $\alpha_{\mathrm{q}}-\mathrm{PLC} \beta 4-\mathrm{PKC} \gamma$ signaling cascade in PCs show multiple CF effects. Although such mice show normal PC dendritic growth, they have motor defects that include ataxia and impaired motor learning [24-26, 44]. Activation of PLC $\beta$ occurs when G $\beta \gamma$ dimers are released from $G_{q}$ and $G_{i / o}$, but the binding sites and activation kinetics differ between $\mathrm{G} \alpha_{\mathrm{q}}$ and $\mathrm{G} \beta \gamma$ [45]. Western analyses indicated that the expression levels of $\mathrm{G} \alpha_{\mathrm{i}}$ and $\mathrm{G} \alpha_{\mathrm{q}}$ were not altered by Gnao-deletion (Fig. $1 \mathrm{~m}$ and Additional file 3). Furthermore, the loss of $\mathrm{G \alpha}_{\mathrm{o}}$ does not increase free Gßy dimers in $\mathrm{Gnao}^{-/-}$mice [8]. Thus, the phenotypes of $\mathrm{Gnao}^{-/-}$mice are more likely due to the loss of some of $\mathrm{G \alpha}_{\mathrm{o}}$ specific unique functions rather than being due to the activation of the G $\beta \gamma$-PLC $\beta$ pathway.

$\mathrm{G}_{\mathrm{i} / \mathrm{o}}$ signals are known to mediate presynaptic inhibitory effects of many neurotransmitters on transmitter release in axon terminals [46]. Activation of $\mathrm{G}_{\mathrm{i} / \mathrm{o}}$-coupled $\mathrm{CB} 1$ receptors decreases glutamate release in presynaptic PF terminals by suppressing $\mathrm{Ca}^{2+}$ entry via voltage-gated $\mathrm{Ca}^{2+}$ channels (N-, P/Q-, and R-types) or modulating vesicle-release related proteins [47-49]. Considering that a CB1 agonist predominantly activates $G_{0}$ in the cerebellum and $G_{0}$ exerts its inhibitory function on $N$ - and $P / Q$ type channels $[16,50]$, the $\mathrm{Ca}^{2+}$ influx in PF terminals is highly likely mediated by the $G_{o}$ signals. In PCs, Pcp2 


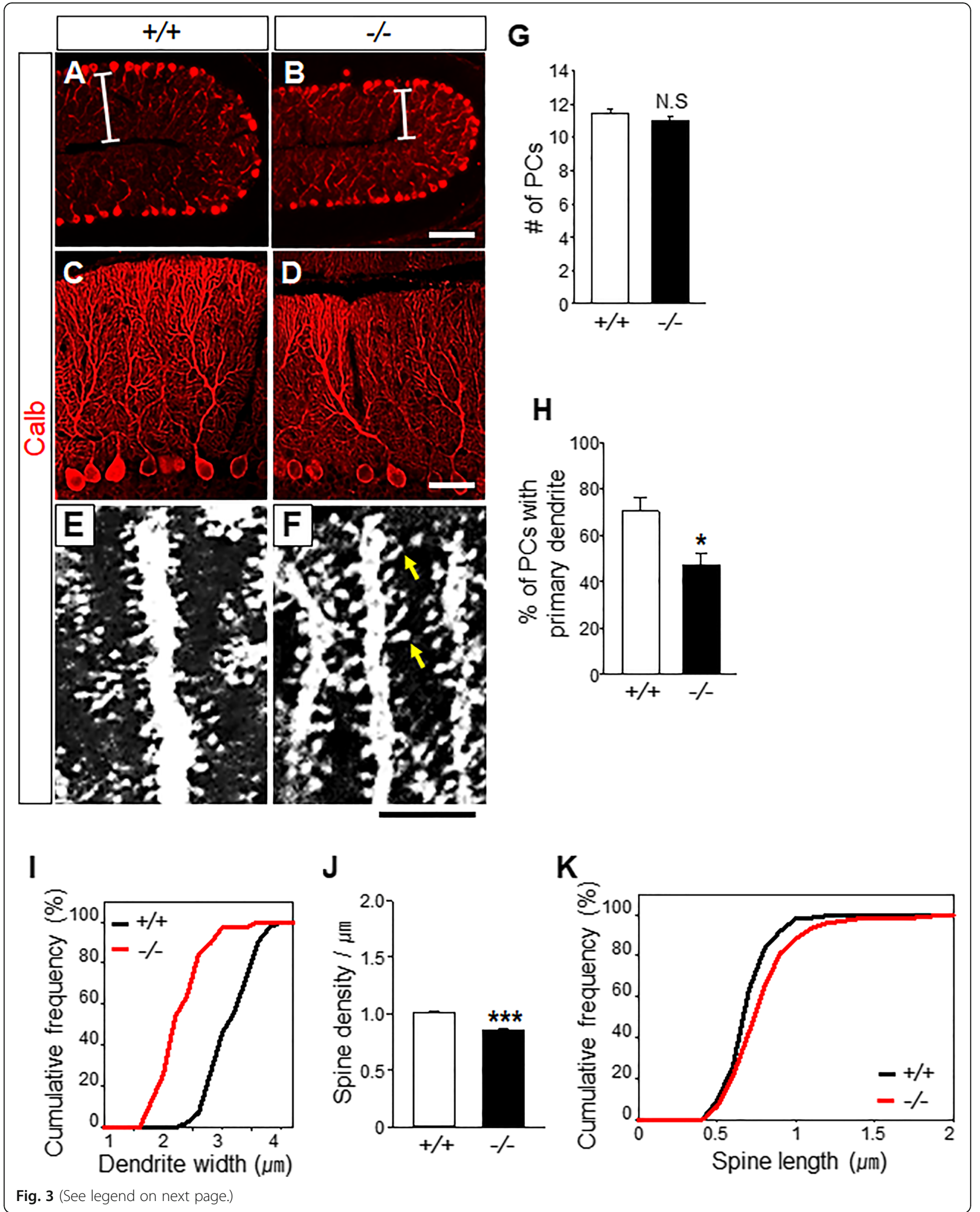


(See figure on previous page.)

Fig. $3 \mathrm{Ga}_{\circ}$ is required for PC maturation. a-b The thickness of the ML is reduced (Bars in a, b) without changing PCL alignment. Scale bar, $100 \mu \mathrm{m}$. c-d Calbindin-D28k (Calb) staining reveals whole PC dendritic trees throughout the ML of the adult cerebellum. Scale bar, $20 \mu \mathrm{m}$ in c-d. e-f Images of dendritic spines detected with an anti-Calb antibody. Arrows indicate spines longer than $1.5 \mu \mathrm{m}$ in $\mathrm{Gnao}^{-1-}$ mice. Scale bar, $5 \mu \mathrm{m}$ in e-f. $\mathbf{g}$ The average number of PCs per $200 \mu \mathrm{m}$ is similar between $\mathrm{Gnao}^{+/+}$mice and $\mathrm{Gnao}^{-/-}$mice $\left(11.5 \pm 0.23\right.$ in $\mathrm{Gnao}^{+/+}$mice and $11.0 \pm 0.30 \mathrm{in} \mathrm{Gnao}^{-/-}$mice; $p=0.232$ vs. $\left.\mathrm{Gnao}^{+/+}\right)$. $\mathbf{h} 70.3 \pm 6.20 \%$ of total PCs in $\mathrm{Gnao}^{+/+}$mice and $47.1 \pm 4.85 \%$ of total PCs in Gnao ${ }^{-/-}$mice extend primary dendrites longer than $30 \mu \mathrm{m}$ ( $n=61$ PCs from $3 \mathrm{Gnao}^{+/+}$mice and 76 PCs from $3 \mathrm{Gnao}^{-1-}$ mice). i Dendritic trunk widths are decreased in Gnao ${ }^{-/-}$mice $(n=41$ primary dendrites from $3 \mathrm{GnaO}^{+/+}$mice and 39 primary dendrites from $3 \mathrm{Gnao}^{-1-}$ mice). $\mathbf{j} \mathrm{Gnao}^{-1-}$ mice exhibit a significant reduction of spine density $(n=123$ segments of 122 distal dendrites from $3 \mathrm{Gnao}^{+/+}$mice and 130 segments of 106 distal dendrites from $3 \mathrm{GnaO}^{-/-}$mice). k Average spine length is longer in $\mathrm{Gnao}^{-/-}$mice $\left(n=210\right.$ dendrite spines from $3 \mathrm{Gnao}^{+/+}$mice and 195 dendrite spines from 3 Gnao ${ }^{-/-}$mice). Data are means \pm SEM; ${ }^{*} p<0.05,{ }^{* * *} p<0.001$ vs. Gnao ${ }^{+/+}$. N.S.; No significant difference

stimulates GDP release from $\mathrm{G \alpha}_{o}$ through its GoLoco domain and modulates the inhibitory functions of $G_{0}$ on P/Qtype $\left(\mathrm{Ca}_{\mathrm{v}} 2.1\right)$ channels $[15,17,51]$. Deletion of Cacna1a, the gene encoding the pore-forming $\alpha_{1}$ subunit of P/Q-type channels in the entire cerebellum or in PCs impairs the maturation of CFs [52, 53]. Pcp2 expression was not altered in our $\mathrm{Gnao}^{-/-}$mice, while the terminal boutons of CFs were atrophied (Fig. 4 and Additional file 3). It would be of great interest to determine whether the functions of voltage-gated $\mathrm{Ca}^{2+}$ channels are altered in $\mathrm{Gnao}^{-/-}$mice.

$\mathrm{G \alpha}_{\mathrm{o}}$ is highly enriched in the cerebellar ML, particularly at the plasma membranes of PC dendrites and in

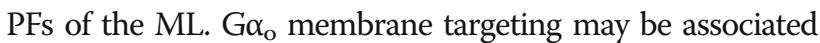
with lipid modifications such as myristoylation or palmitoylation [54]. The distinctive membrane compartmentalization of $\mathrm{G \alpha}_{\mathrm{o}}$ in PCs (Table 1) makes it well-suited to perform synapse-specific studies. Consistent with our data, $\mathrm{G \alpha}_{\mathrm{o}}$ appears at high levels in postsynaptic densities in vivo as well as in the neurite tips and growth cones of in vitro cultured neurons [7, 12, 13, 55]. Consistently, we show that $\mathrm{G \alpha}_{\mathrm{o}}$ is found in the sprouting dendrites of PCs in P7 cerebellum (Fig. 2b). It is noteworthy that migration of granule cells from EGL to GCL appear normal, suggesting that the Bergman's glia functions properly.
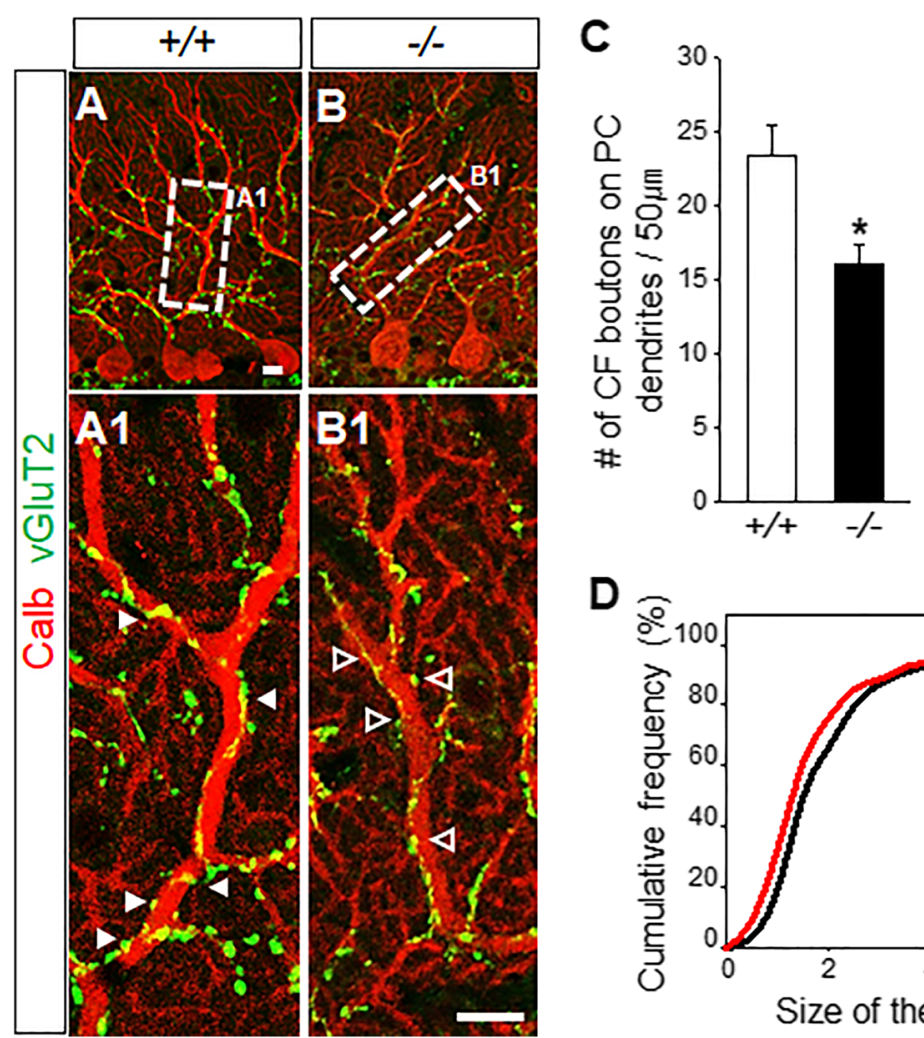

D

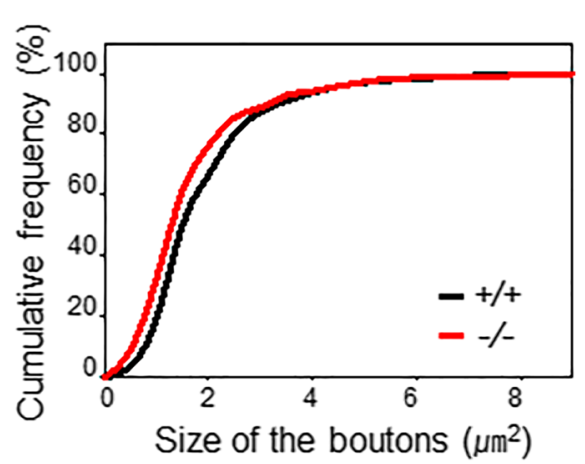

Fig. $4 \mathrm{Ga}_{\circ}$ is required for the maturation of CF-PC synapses. $\mathbf{a}-\mathbf{b} \mathrm{Gnao}^{-1-}$ mice show atrophied vGluT2-positive morphology of CF synaptic boutons

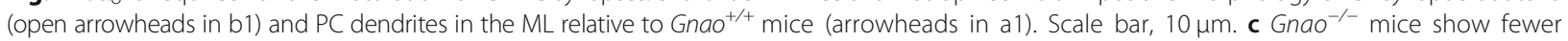
vGluT2-positive dendritic boutons ( $n=9$ main dendrites from $4 \mathrm{Gnao}^{+/+}$mice and $n=7$ main dendrites from $4 \mathrm{Gnao}^{-/-}$mice). d Bouton size is smaller in $\mathrm{Gnao}^{-/-}$mice (P25) ( $n=655$ vGluT2-positive boutons from $4 \mathrm{Gnao}^{+/+}$mice and $432 \mathrm{vGluT2-positive} \mathrm{boutons} \mathrm{from} 4 \mathrm{Gnao}^{-/-}$mice). Data are means \pm SEM; ${ }^{*} p<0.05$, ${ }^{* *} p<0.005$ vs. Gnao ${ }^{+/+}$ 
In conclusion, our study suggests $G_{o}$ may perform critical roles in the postnatal development of the cerebellar cortex. Future studies cell type specific deletion of Gnao will reveal the correlation of intrinsic signaling pathways in cerebellar cortical neurons with PF-PC synapse and CF-PC synapse. Gabra6 ( $\Delta \alpha 6)$ - and Pcp2(L7)-driven Cre-expressing mice have been utilized for the study of GCs and PCs, respectively [56-58]. However, $\mathrm{G \alpha}_{\mathrm{o}}$ protein is detectable due to its high stability even after the Gnao gene is deleted by Cre enzymes in postnatal neurons (data not shown). Inducible Cre mouse lines such as Gli1-CreER ${ }^{T 2}$ may be an alternative strategy to induce concomitant deletion of the Gnao gene and the existing $\mathrm{G \alpha}_{\mathrm{o}}$ proteins in proliferating EGL cells [59].

\section{Additional files}

Additional file 1: The gross anatomy of the cerebellum is normal in $\mathrm{Gnao}^{-/-}$mice. (PDF $187 \mathrm{~kb}$ )

Additional file 2: PFs in the ML visualized in vGluT1-stained cerebellum. (PDF $85 \mathrm{~kb}$ )

Additional file 3: Expression of Pcp2 in the cerebellum of $\mathrm{GnaO}^{-1-}$ mice. (PDF $380 \mathrm{~kb}$ )

\section{Abbreviations}

AC: Adenylyl cyclase; Calb: Calbindin-D28K; cAMP: Cyclic AMP, 3',5'-cyclic adenosine monophosphate; CB1: Cannabinoid receptor 1; CFs: Climbing fibers; CNS: Central nervous system; DCN: Deep cerebellar nuclei; DEPC: Diethylpyrocarbonate; DIV: Days in vitro; DMEM: Dulbecco's modified Eagle medium; EGL: External granule layer; EIEE: Early infantile epileptic encephalopathy; FBS: Fetal bovine serum; FITC: Fluorescein isothiocyanate; GCL: Granule cell layer; GCs: Granule cells; GPCRs: G-protein coupled receptors; G-proteins: GTP binding proteins; Ga: GTP-binding Protein alpha subunit of $\mathrm{G}_{0}$; HBSS: Hank's balanced salt solution; ION: Inferior olivary nucleus; mGluR1: Metabotropic glutamate receptor type 1; ML: Molecular layer; N.S.: No significant; NBF: Neutral buffered formalin; ND: Not Determined; P: Postnatal day; PBS: Phosphate buffered saline; PCL: Purkinje cell layer; Pcp2: Purkinje cell protein 2; PCR: Polymerase chain reaction; PCs: Purkinje cells; PDL: Poly-D-lysine; PFs: Parallel fibers; PKC : Protein kinase Cy; PLCß4: Phospholipase Cß4; SDS: Sodium dodecyl sulfate; SEM: Standard error of mean; SSC: Saline-sodium citrate; STD: Standard marker; TBS: Trisbuffered saline; vGluT1/2: Vesicular glutamate transporter 1/2

\section{Acknowledgements}

We thank Dr. Serena Dudek (National Institute of Environmental Health Sciences) for helpful comments.

\section{Authors' contributions}

HLC, J-MC, H-HO and NB performed experiments; HLC, J-MC, Y-DL and S-SK conducted analyses of the data; LB and HS-K supervised the research; HLC, J-MC, LB and HS-K wrote the manuscript. All authors read and approved the final manuscript.

\section{Funding}

This research was supported by the Bio \& Medical Technology Development Program of the National Research Foundation (NRF) funded by the Korean government (MSIT) (2018M3A9G1082594 to HS-K and 2017R1D1A1B03028120 to J-MC) and by the Intramural Research Program of the NIH (Project Z01-ES101643 to LB).

\section{Availability of data and materials}

All of the data generated and analyzed in this study are included in the published article.

\section{Ethics approval}

All experimental procedures involving the use of animals were reviewed and approved by the Institutional Animal Research Ethics Committee at Ajou University Medical Center.

\section{Consent for publication}

Not applicable.

\section{Competing interests}

HS-K is a member of scientific board of Cell\&Brain, a company studying the potential therapeutic use of mesenchymal stem cell. The all authors declare that the research was conducted in the absence of any commercial or financial relationships that could be construed as a potential conflict of interest.

\section{Author details}

'Departments of Anatomy, Ajou University School of Medicine, Woldcup-ro 164, Yeongtong-gu, Suwon 16499, South Korea. ${ }^{2}$ Departments of Biomedical Sciences, The Graduate School, Ajou University School of Medicine, World cup-ro 164, Yeongtong-gu, Suwon 16499, South Korea. ${ }^{3}$ Neurobiology Laboratory, National Institute of Environmental Health Sciences, Research Triangle Park, Durham 27709, NC, USA. ${ }^{4}$ Institute of Biomedical Research (BIOMED), School of Medical Sciences, Catholic University of Argentina, Av. Alicia Moreau de Justo 1300, Edificio San Jose Piso 3, C1107AAZ Buenos Aires, Argentina.

Received: 28 January 2019 Accepted: 29 May 2019

Published online: 20 June 2019

\section{References}

1. Simon MI, Strathmann MP, Gautam N. Diversity of G proteins in signal transduction. Science. 1991:252:802-8

2. Neer EJ. Heterotrimeric $G$ proteins: organizers of transmembrane signals. Cell. 1995:80:249-57.

3. Birnbaumer $L$. Expansion of signal transduction by $G$ proteins. The second 15 years or so: from 3 to 16 alpha subunits plus betagamma dimers. Biochim Biophys Acta. 2007;1768:772-93.

4. Rudolph U, Finegold MJ, Rich SS, Harriman GR, Srinivasan Y, Brabet $P$, et al. Gi2 alpha protein deficiency: a model of inflammatory bowel disease. J Clin Immunol. 1995;15:101S-5S.

5. Devanathan V, Hagedorn I, Kohler D, Pexa K, Cherpokova D, Kraft P, et al. Platelet Gi protein Galphai2 is an essential mediator of thromboinflammatory organ damage in mice. Proc Natl Acad Sci U S A. 2015; 112:6491-6

6. Boknik P, Grote-Wessels S, Barteska G, Jiang M, Muller FU, Schmitz W, et al. Genetic disruption of $\mathrm{G}$ proteins, $\mathrm{G}(\mathrm{i} 2)$ alpha or $\mathrm{G}(\mathrm{0})$ alpha, does not abolish inotropic and chronotropic effects of stimulating muscarinic cholinoceptors in atrium. Br J Pharmacol. 2009;158:1557-64.

7. Sharma K, Schmitt S, Bergner CG, Tyanova S, Kannaiyan N, Manrique-Hoyos $\mathrm{N}$, et al. Cell type- and brain region-resolved mouse brain proteome. Nat Neurosci. 2015:18:1819-31.

8. Jiang M, Gold MS, Boulay G, Spicher K, Peyton M, Brabet P, et al. Multiple neurological abnormalities in mice deficient in the $G$ protein go. Proc Nat Acad Sci U S A. 1998:95:3269-74

9. Choi JM, Kim SS, Choi Cl, Cha HL, Oh HH, Ghil S, et al. Development of the main olfactory system and main olfactory epithelium-dependent male mating behavior are altered in go-deficient mice. Proc Natl Acad Sci U S A. 2016:113:10974-9.

10. Nakamura K, Kodera H, Akita T, Shiina M, Kato M, Hoshino H, et al. De novo mutations in GNAO1, encoding a Galphao subunit of heterotrimeric G proteins, cause epileptic encephalopathy. Am J Hum Genet. 2013;93: 496-505.

11. Talvik I, Moller RS, Vaher M, Vaher U, Larsen LH, Dahl HA, et al. Clinical phenotype of De novo GNAO1 mutation: case report and review of literature. Child neurology open. 2015:2:2329048X15583717.

12. Strittmatter SM, Valenzuela D, Vartanian T, Sudo Y, Zuber MX, Fishman MC Growth cone transduction: go and GAP-43. J Cell Sci Suppl. 1991;15:27-33.

13. Ghil SH, Kim BJ, Lee YD, Suh-Kim H. Neurite outgrowth induced by cyclic AMP can be modulated by the alpha subunit of go. J Neurochem. 2000;74: $151-8$.

14. Worley PF, Baraban JM, Van Dop C, Neer EJ, Snyder SH. Go, a quanine nucleotide-binding protein: immunohistochemical localization in rat brain 
resembles distribution of second messenger systems. Proc Natl Acad Sci U S A. 1986:83:4561-5.

15. Luo $Y$, Denker BM. Interaction of heterotrimeric $G$ protein Galphao with Purkinje cell protein-2. Evidence for a novel nucleotide exchange factor. J Biol Chem. 1999;274:10685-8.

16. Prather PL, Martin NA, Breivogel CS, Childers SR. Activation of cannabinoid receptors in rat brain by WIN 55212-2 produces coupling to multiple G protein alpha-subunits with different potencies. Mol Pharmacol. 2000;57:1000-10.

17. Iscru E, Serinagaoglu Y, Schilling K, Tian J, Bowers-Kidder SL, Zhang R, et al. Sensorimotor enhancement in mouse mutants lacking the Purkinje cellspecific Gi/o modulator, Pcp2(L7). Mol Cell Neurosci. 2009;40:62-75.

18. Cerminara NL, Lang EJ, Sillitoe RV, Apps R. Redefining the cerebellar cortex as an assembly of non-uniform Purkinje cell microcircuits. Nat Rev Neurosci. 2015;16:79-93

19. Ichikawa R, Hashimoto K, Miyazaki T, Uchigashima M, Yamasaki M, Aiba A, et al. Territories of heterologous inputs onto Purkinje cell dendrites are segregated by mGluR1-dependent parallel fiber synapse elimination. Proc Natl Acad Sci U S A. 2016;113:2282-7.

20. Watanabe $M$, Kano M. Climbing fiber synapse elimination in cerebellar Purkinje cells. Eur J Neurosci. 2011;34:1697-710.

21. Kaneko M, Yamaguchi K, Eiraku M, Sato M, Takata N, Kiyohara $Y$, et al. Remodeling of monoplanar Purkinje cell dendrites during cerebellar circuit formation. PLoS One. 2011;6:e20108.

22. Sotelo C, Dusart I. Intrinsic versus extrinsic determinants during the development of Purkinje cell dendrites. Neuroscience. 2009;162:589-600.

23. Schuller U, Lamp EC, Schilling K. Developmental expression of heterotrimeric G-proteins in the murine cerebellar cortex. Histochem Cell Biol. 2001;116:149-59.

24. Kano M, Hashimoto K, Kurihara $H$, Watanabe M, Inoue $Y$, Aiba A, et al. Persistent multiple climbing fiber innervation of cerebellar Purkinje cells in mice lacking mGluR1. Neuron. 1997;18:71-9.

25. Offermanns S, Hashimoto K, Watanabe M, Sun W, Kurihara H, Thompson RF, et al. Impaired motor coordination and persistent multiple climbing fiber innervation of cerebellar Purkinje cells in mice lacking Galphaq. Proc Natl Acad Sci U S A. 1997;94:14089-94.

26. Hashimoto $K$, Watanabe M, Kurihara H, Offermanns S, Jiang H, Wu Y, et al. Climbing fiber synapse elimination during postnatal cerebellar development requires signal transduction involving $\mathrm{G}$ alpha $\mathrm{q}$ and phospholipase $\mathrm{C}$ beta 4. Prog Brain Res. 2000;124:31-48.

27. Furuya S, Makino A, Hirabayashi Y. An improved method for culturing cerebellar Purkinje cells with differentiated dendrites under a mixed monolayer setting. Brain Res Brain Res Protoc. 1998;3:192-8.

28. Fujishima K, Horie R, Mochizuki A, Kengaku M. Principles of branch dynamics governing shape characteristics of cerebellar Purkinje cell dendrites. Development. 2012;139:3442-55.

29. Rieff HI, Raetzman LT, Sapp DW, Yeh HH, Siegel RE, Corfas G. Neuregulin induces GABA(a) receptor subunit expression and neurite outgrowth in cerebellar granule cells. J Neurosci. 1999;19:10757-66.

30. Wechsler-Reya RJ, Scott MP. Control of neuronal precursor proliferation in the cerebellum by sonic hedgehog. Neuron. 1999;22:103-14.

31. Leto K, Arancillo M, Becker EB, Buffo A, Chiang C, Ding B, et al. Consensus Paper: Cerebellar Development. Cerebellum. 2016;15:789-828.

32. Choi Cl, Yoon SP, Choi JM, Kim SS, Lee YD, Birnbaumer $L$, et al. Simultaneous deletion of floxed genes mediated by CaMKIlalpha-Cre in the brain and in male germ cells: application to conditional and conventional disruption of Goalpha. Exp Mol Med. 2014;46:e93.

33. Schneider CA, Rasband WS, Eliceiri KW. NIH image to ImageJ: 25 years of image analysis. Nat Methods. 2012;9:671-5.

34. Donald S, Humby T, Fyfe I, Segonds-Pichon A, Walker SA, Andrews SR, et al. P-Rex2 regulates Purkinje cell dendrite morphology and motor coordination. Proc Natl Acad Sci U S A. 2008;105:4483-8.

35. von Bohlen Und Halbach O. Structure and function of dendritic spines within the hippocampus. Ann Anat. 2009;191:518-31.

36. Espinosa JS, Luo L. Timing neurogenesis and differentiation: insights from quantitative clonal analyses of cerebellar granule cells. J Neurosci. 2008;28: 2301-12.

37. Legue E, Gottshall JL, Jaumouille E, Rosello-Diez A, Shi W, Barraza LH, et al. Differential timing of granule cell production during cerebellum development underlies generation of the foliation pattern. Neural Dev. 2016;11:17.

38. Largent BL, Jones DT, Reed RR, Pearson RC, Snyder SH. G protein mRNA mapped in rat brain by in situ hybridization. Proc Natl Acad Sci U S A. 1988; 85:2864-8.
39. Brann MR, Collins RM, Spiegel A. Localization of mRNAs encoding the alphasubunits of signal-transducing G-proteins within rat brain and among peripheral tissues. FEBS Lett. 1987;222:191-8.

40. Korbo L, Andersen BB, Ladefoged O, Moller A. Total numbers of various cell types in rat cerebellar cortex estimated using an unbiased stereological method. Brain Res. 1993;609:262-8.

41. Weisheit G, Gliem M, Endl E, Pfeffer PL, Busslinger M, Schilling K. Postnatal development of the murine cerebellar cortex: formation and early dispersal of basket, stellate and Golgi neurons. Eur J Neurosci. 2006;24:466-78.

42. Qin L, Wine-Lee L, Ahn KJ, Crenshaw EB 3rd. Genetic analyses demonstrate that bone morphogenetic protein signaling is required for embryonic cerebellar development. J Neurosci. 2006;26:1896-905.

43. Hashimoto K, Kano M. Synapse elimination in the developing cerebellum. Cell Mol Life Sci. 2013;70:4667-80.

44. Hashimoto K, Ichikawa R, Takechi H, Inoue Y, Aiba A, Sakimura K, et al. Roles of glutamate receptor delta 2 subunit (GluRdelta 2) and metabotropic glutamate receptor subtype 1 (mGluR1) in climbing fiber synapse elimination during postnatal cerebellar development. J Neurosci. 2001; 21:9701-12.

45. Lyon AM, Tesmer JJ. Structural insights into phospholipase C-beta function. Mol Pharmacol. 2013;84:488-500.

46. Brown DA, Sihra TS. Presynaptic signaling by heterotrimeric G-proteins. Handb Exp Pharmacol. 2008:207-60.

47. Kreitzer AC, Regehr WG. Retrograde signaling by endocannabinoids. Curr Opin Neurobiol. 2002;12:324-30.

48. Zhang W, Linden DJ. Neuromodulation at single presynaptic boutons of cerebellar parallel fibers is determined by Bouton size and basal action potential-evoked ca transient amplitude. J Neurosci. 2009;29:15586-94.

49. Hoxha E, Tempia F, Lippiello P, Miniaci MC. Modulation, plasticity and pathophysiology of the parallel Fiber-Purkinje cell synapse. Front Synaptic Neurosci. 2016;8:35.

50. Furukawa T, Miura R, Mori Y, Strobeck M, Suzuki K, Ogihara Y, et al. Differential interactions of the $\mathrm{C}$ terminus and the cytoplasmic I-II loop of neuronal Ca2+ channels with G-protein alpha and beta gamma subunits. II. Evidence for direct binding. J Biol Chem. 1998;273:17595-603.

51. Kinoshita-Kawada M, Oberdick J, Xi Zhu M. A Purkinje cell specific GoLoco domain protein, L7/Pcp-2, modulates receptor-mediated inhibition of Cav2. $1 \mathrm{Ca} 2+$ channels in a dose-dependent manner. Brain Res Mol Brain Res. 2004;132:73-86.

52. Miyazaki T, Hashimoto K, Shin HS, Kano M, Watanabe M. P/Q-type Ca2+ channel alpha1A regulates synaptic competition on developing cerebellar Purkinje cells. J Neurosci. 2004;24:1734-43.

53. Hashimoto K, Tsujita M, Miyazaki T, Kitamura K, Yamazaki M, Shin HS, et al. Postsynaptic P/Q-type Ca2+ channel in Purkinje cell mediates synaptic competition and elimination in developing cerebellum. Proc Natl Acad Sci U S A. 2011;108:9987-92.

54. Chen CA, Manning DR. Regulation of $\mathrm{G}$ proteins by covalent modification. Oncogene. 2001;20:1643-52.

55. Fernandez E, Collins MO, Uren RT, Kopanitsa MV, Komiyama NH, Croning MD, et al. Targeted tandem affinity purification of PSD-95 recovers core postsynaptic complexes and schizophrenia susceptibility proteins. Mol Syst Biol. 2009;5:269.

56. Aller Ml, Jones A, Merlo D, Paterlini M, Meyer AH, Amtmann U, et al. Cerebellar granule cell Cre recombinase expression. Genesis. 2003;36:97-103.

57. Slugocka A, Wiaderkiewicz J, Barski JJ. Genetic targeting in cerebellar Purkinje cells: an update. Cerebellum. 2017;16:191-202.

58. Zhang XM, Ng AH, Tanner JA, Wu WT, Copeland NG, Jenkins NA, et al. Highly restricted expression of Cre recombinase in cerebellar Purkinje cells. Genesis. 2004:40:45-51.

59. Ahn S, Joyner AL. Dynamic changes in the response of cells to positive hedgehog signaling during mouse limb patterning. Cell. 2004;118:505-16.

\section{Publisher's Note}

Springer Nature remains neutral with regard to jurisdictional claims in published maps and institutional affiliations. 